\title{
Differences in Perception of the Participants in the Management Process and Its Real Trajectory
}

\section{Olaf Flak*, Adrian Pyszka**}

\begin{abstract}
The aim of the paper is to present results of the research that was focused on managers' behaviours. We tried to discover the main differences between the real trajectory and perception of managers in the field of two types of management processes. In the first part of the paper there is a theoretical foundation of process management and conclusions that led to a research model. In the second part we present the state of art in the field of human perception theories. Then, we describe assumptions of the research and methods of gathering data. What is important in the case of research method, an observation and a survey were used. The observation was done using the online management tools. During the research, managers were given a small project to lead. We recorded their actions and when their projects were completed, we asked them how they had acted. As a result of the research, there are three examples of description of managers' behaviours and their perception. In the introduction we formulated two hypotheses and on the grounds of the research result we prove both statements in conclusion of the paper.
\end{abstract}

Keywords: process management, human perception, trajectory of processes, system of organizational terms.

\section{Introduction}

It is said that "the legacy of the past is always shaping the emerging future" (Pettigrew, 1997, p. 339). The process-oriented holistic organization was found as a new form in which the business process may be perceived as the basic organizational construct. Although in quite old management schools the process existed as a term, process management implies a complex focus on business processes. They tend to be integrated with one another. The increasing organizational complexity of processes results in new demands on

* Olaf Flak, Ph.D., University of Silesia in Katowice, ul. Bankowa 12, 40-007 Katowice, Poland, ja@olafflak.com.

** Adrian Pyszka, Ph.D., University of Economics in Katowice, ul. 1 Maja 50, 40-287 Katowice, Poland, adrian.pyszka@ue.katowice.pl. 
a firm's information management. This complexity also needs to be managed (Seltsikas, 1999, p. 181).

Facing the importance and vital role of process management in the development and organizational change of companies the question arises how different managers perform in their projects or linear activities (Rohloff, 2011, p. 384). It is frequently forgotten that everything starts from philosophy of an action that means a systematic way of thinking and doing. Actions permeate an organization. Everything the organization does and considers is affected by the philosophy that does not change very often. The next step is a business model, which is the framework for identifying how a business creates, delivers, and extracts value (Dowdle, Stevens, McCarty and Daly, 2005 , p. 58). In the paper we focus on two items deriving from a business model: methods and tools of management (Dowdle et al., 2005, p. 58). These areas create the basis of research of process management in small projects.

In the paper there is a presentation of results of the research in the field of process management. Although there are exceptions, the general method of the research might be treated as a case study. The reason is there were only 8 managers who took part in the research. The main task for managers was to prepare an implementation manual for an innovative management tool. There were two ways of collecting data: an observation and a survey. On the one hand, in the paper there is a short draft of real facts gathered by the observation method. The observation was conducted using online management tools implemented in www.transistorshead.com (TH management tools). On the other hand, we surveyed the managers who used the tools just after finishing their projects.

Management tools that base on the system of organizational terms (Flak, 2008, pp. 13-21), allowed to do the research on processes and give answers to questions such as what happens in the organization, how it happens, what results are obtained from processes and what the rhythm of the processes is.

The main goal of the paper is to discover the main differences between the real trajectory and perception of managers in the field of two types of management processes. We formed the following hypotheses:

H1. Managers are not conscious of most of their activities in management process.

H2. The scale of a project, labelled by the number of processes, does not influence the level of managers' consciousness.

In the first part of the paper there is some theoretical foundation of process management. On grounds of theories some conclusions were drawn that led to an abstract model of the research. In the next part, we presented the state of art in the field of human perception. This part in combination with the process management background allowed us to verify hypotheses. 
In the middle part of the paper there is a description of the observation and questionnaire profiles and there is also a description of comparisons between perception of managers and the real trajectory of processes.

\section{Theoretical background of management processes}

The scale of complexity can be drawn as symbolic processes mixed with one another. A large number of processes leads to process contributions and to obtain or to lose strategic goals of organizations. In some period of time strategic goals result in creating desirable future states that are called visions of entrepreneurs, managers and companies' owners. These correlations are shown in the Figure 1.

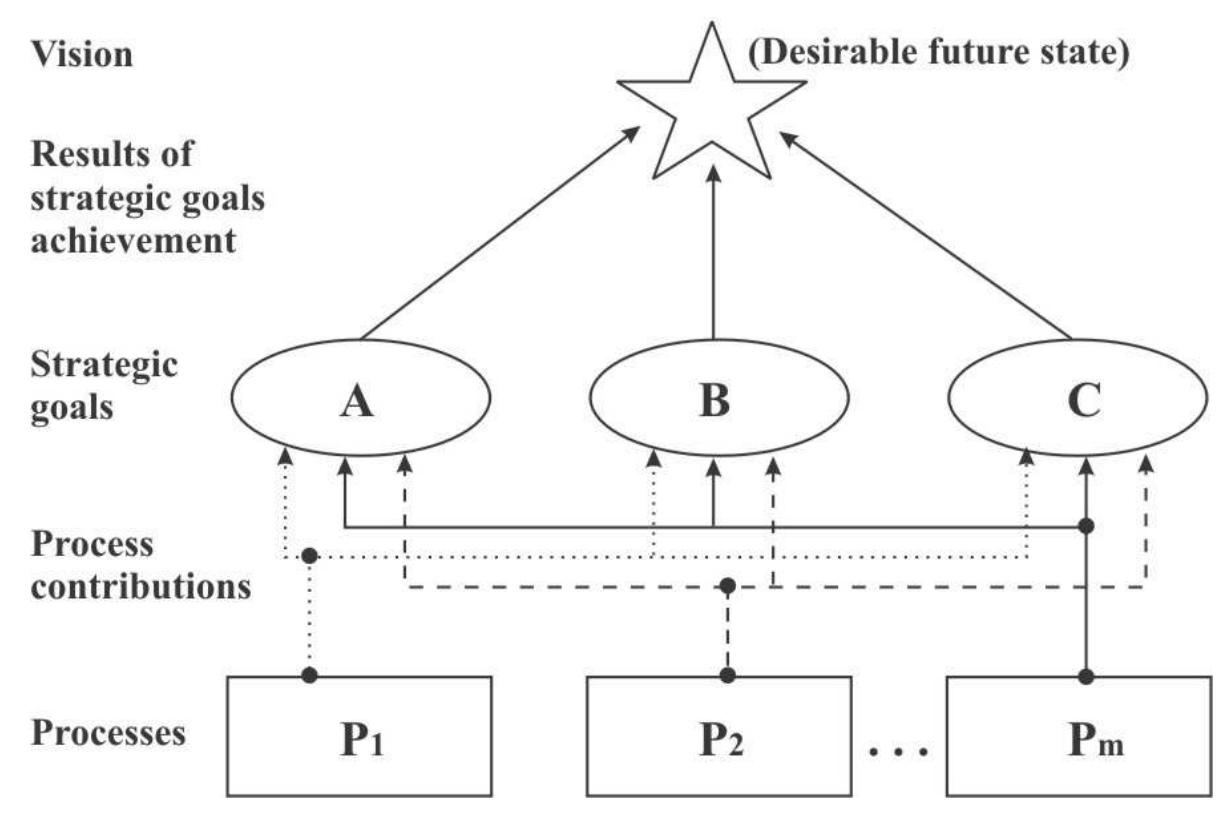

Figure 1. Correlations between processes and their effects Source: Seltsikas (1999), p. 186.

Time is a central point in preoccupation of the process management. The dynamics of the process is only possible to reveal with temporality and a timeline. It allows discovering the relationships between the past, present and the future. What is more, there are also relationships, called interrelationships, between different levels of context of emerging processes. These relationships are also between effects of processes (Pettigrew, 1997, p. 345).

A well-known and largely used practice in the field of processes is Business Process Management (BPM). The management practice encompasses all 
activities of identification, definition, analysis, design, execution, monitoring, measurement and continuous improvement of business processes (Rohloff, 2011, p. 383).

In order to close the gap and provide methodological support for a BPM assessment an analysis on obtainable methods for an assessment was undertaken based on academic work and industry practice (Rohloff, 2011, p. 392).

There are 5 stages of process management maturity level (Rohloff, 2011, p. 394):

1) Initial - processes are not defined; schedules, quality and costs are not predictable

2) Managed - there is a need for identification because of event approach to management

3) Defined-only strategically relevant processes are documented according to reference processes books

4) Quantitative Managed - there is continuous measurement and adjustment of processes performance; there is also a strong impact on implementation controlling

5) Optimizing-Best practices are being shared, there is also a benchmarking in order to optimize all processes

Another background of the research is an additional approach to process management that is called Knowledge Management System (KMS). Process maps are a key element of the KMS to facilitate some issues more effectively than other approaches (Keane, Barber and Munive-Hernandez, 2007, p. 134). In the next section of the paper there is a description of how this approach was used in building the TH management tools.

In papers that concern the topic of process management we can find many definitions of the process. It is possible to quote a part of the research into associations with processes. The interviewers enumerated words as followed (Pettigrew, 1997): "flow of events, chronology, mechanism, unfolding, two forces interacting, time, language, context, outcomes, linking things together, individuals and collectiveness, history, consistent story, change, long period." (p. 338) Taking into consideration these associations there is still a strong need to define what the process really is.

Projecting the system of organizational terms, which was mentioned above as a basis of empiric research presented in this paper, we assumed that the process of management is a collection of sequential activities with causal correlations. These correlations mean that the results of previous activities are necessary for the existence of next activities. These results become an input for the next activities (Grajewski, 2007, p. 55). For the sake of the observation we formed a precise definition of the process. This definition was presented by Pettigrew. He claimed that a process is (Pettigrew, 1997) "a sequence of 
individual and collective events, actions, and activities unfolding over time in context" (p. 338).

Another perspective, which was necessary to take into consideration, was team management. Because the processes in the company are partly collective, this approach let us understand how to project feature vectors of processes that we expected to achieve during the observation. From this point of view, we can treat every process as a set of activities that are serial or parallel. They are being caused by humans individually or collectively. Theoretically, these activities are in some order and they should proceed to the desired goal. (Skrzypek and Hofman, 2010, pp. 13-14). The "goal" term is understood by us more generally. It is an expected and necessary result of these activities.

In order to understand the effect of the observation, it is necessary to describe what the border states of processes are and how they influence a way of measurement. In the system of organizational terms there is an "event" term. It belongs to substantial assumptions of the system of organizational terms and the TH management tools. There is a strong need to quote an original definition used in the system of organizational terms. According to Zieleniewski (1961, after: Shackle, 1961, p. 4) "the event occurs when two states of the world, appointed in different moments of time, differ one from another and this difference did not occur because of the flow of time." (p. 4)

When we take into consideration the observation and management tools used to record managers' activities, this definition is important because a recording process took place within a timeline. In separate moments of time the management tools recorded conducting management process by managers. These data records created the featured vectors of processes. The changes in the parameters inside the feature vector were treated as proceedings.

A process perspective also involves process metrics. These are variables or measures within the feature vector. They are defined to monitor "each step" of processes. P. Seltsikas claims that metrics can identify where a process is not correct and this information can be used for process improvement. He gives examples of metrics of processes such as time and cost (Seltsikas, 1999, 191). However, these measures are very general. In the TH management tools every process has its own parameters that were shaped in the feature vector. The examples of two processes - setting goals and describing tasks - are presented in the next sections of the paper.

This way we could meet 3 demands that concern measuring processes. Firstly, a process is usually used as a kind of logic to explain causal relations between objects in management (in the system of organizational terms these objects are called "things"). Secondly, a process is a category of concepts that 
refers to activities taken by individuals or teams. Thirdly, a process spreads on a sequence of events. These events, as it was mentioned above, describe how states of the world change over the time. However, we should not take into consideration the influence of time (Pettigrew, 1997, 169).

The assumptions of the system of organizational terms and the $\mathrm{TH}$ management tools were designed to provide an answer to questions raised by T. A. El-Diraby, C. Lima and B. Feis. They built a characteristic of the process consisted from 6 items which are as follows: (1) types of the processes, (2) main attributes of processes (other words: their features vectors), (3) doers of the processes, (4) who is involved in the processes, (5) the effects of processes, (6) conditions which make the processes happen (El-Diraby, Lima and Feis, 2005, 396).

\section{Human perception}

Perception could be seen as the representation (an idea or an image) of what is perceived, a basic component in the formation of a concept, a way of conceiving something, knowledge gained by perceiving, becoming aware of something via the senses. It is important to note that a perception process resides within the individuals and it derives from their own observations. According to Bem's (1972, after: Robak and Ward, 2006, pp. 337-338) selfperception theory, everyone comes to know oneself in the same way that we come to know others. It means that people observe their own behaviours in a variety of situations and make attributions about these behaviours as a parsimonious explanation of self-definition. By this process a human starts self-understanding derived from actively inducing changes and observing results (DeCharms, 1983, p. 268).

The most essential assumption is that individuals may have little direct introspective access to their own higher order cognitive processes (Nisbett and Wilson, 1977, after: Robak and Ward, 2006, p. 337), because people are unaware of the existence of the stimuli that influenced their responses. They are also unaware of their responses. Following Laird and Bresler's (1992) phenomenon of feelings and behaviours, people are simply left to rely on the observation of their own behaviours in order to make causal attributions about them. It is especially visible in the situation when people feel something and report it, even when they are not aware of how they act. For the behaviourists, since individuals learn by reinforcement, the problem of how we learn such things as what we feel and who we are is particularly tricky. The reason is that others do not know our feelings. We may learn to identify events that are outside of our-selves by being rewarded for a correct naming of something (Robak and Ward, 2006, p. 338). 
We conclude that the reinforcement process of learning and recognizing feelings and correct behaviours is an introduction to understand behaviours in organizations, where a self -regulation is a process in such fields as setting goals, describing tasks, engaging in goal-driven behaviours and contemplating goal-related feedback. That is important to facilitate the attainment and maintenance of a desired end state of human beings (Lord, Diefendorff, Schmidt, and Hall, 2010; Vancouver and Day, 2000 after: Bolino, Jaron, Bachrach, 2012, p. 128). Individuals constantly plan and strive for their goals because the self-regulation process is continuous. Goals are being set and adjusted following to the receipt of continual feedback process. This indicates either a success or a failure of attainment a desired end.

According to the self-regulation model we can capture how a selfregulatory system is established and maintained, during four phases of regulations: (1) predecisional phase - individuals adopt a mindset, consider their desires, and set goals; (2) preactional phase - individuals switch to an implemental mindset and consider ways to accomplish their goals (people consider the desirability of their goal and potential ways to goal achievement); (3) actional phase - individuals adopt an actional mindset and try to obtain their goals (individuals encounter obstacles which may, depending on the importance of the goal, lead to an adjustment of effort); (4) postactional phase - associated with an evaluative mindset (individuals evaluate their goals, determine whether they have been achieved, and make decisions about their revision - people may decide to continue to strive for the original goal, change the goal, or disengage from it) (Gollwitzer, 1990, after: Bolino, Jaron, Bachrach, 2012, p. 128).

Dholakia, Bagozzi and Gopinath (2007) stated that in the process of perception it is important to identify and provide an understanding of two specific self-regulatory strategies: (1) formulating an implementation of a plan, and (2) remembering past actions. Using this explanation the selfregulation process is dependent on the individuals' freedom of choice. There are two opposite situations assigned to individuals' decision process: (1) goals that decision makers chose for themselves - the motivational effects lay in increasing levels of implementation-related variables; (2) goals which were assigned to participants - motivational effects additionally extended to significantly increasing distal goal-related variables.

According to the present state of art, there are others explanations of selfregulation strategies. One strategy is to formulate a detailed implementation plan. The second strategy is to remember actions performed successfully in the past to accomplish a similar goal (Armitage, 2004; Gollwitzer, 1999, after: Dholakia, Bagozzi and Gopinath, 2007, p. 361) claimed that retrieving selfperformed actions from the past is relatively less effortful than information 
processing involved in formulating an implementation plan. Remembering past actions is similar in process to recognition memory for retrospective tasks.

Information processing is supported by the attentional processes that work in conjunction with inference, judgment, and choice processes. As a consequence, acts of attention may be able to prime acts of process because attention is a content driven process. A combination of a content and an attention may be able to point typically considered higher-order cognitive processes (e.g., investigate, evaluate, compare, choose, consume) (Janiszewski, Kuo, Tavassoli, 2013, p.1271).

When we consider remembering as a process of constructing a relationship between the past and present, it implies choices and exclusions are made in mnemonic accounts, and suggests that other versions of the past may have been possible. Based on experience from neurology and psychoanalysis, the examination of remembering has been focused on the individual human subject and their acts, revealing the biological fragility and psychic constructedness of memory. Remembering is an active reconciliation of the past and present but it could be selective because of some experiences that are omitted from memory (traumatic or socially unacceptable experiences i.e. childhood sexual abuse) (Keightley, 2010, p. 57).

When we projected the research, we had to consider that memory is not located solely "in the mind", as symbolic representations or mental models. As proposed by Arnold, Shepherd and Gibbs (2008), memory is distributed. It resides in things, in relations between things, and relations between things and humans. In this context this implies that relations between things and people consist of minds and things, and people and things constitute "actors in relation" rather than "actors in themselves" (Latour, 1999; Law \& Hassard, 1999; Latour, 2005, after: Arnold, Shepherd, Gibbs, 2008, p. 48).

According to above Arnold and colleagues argue four significant for memory assumptions: (1) relations between things are crucial; (2) things provide us with markers of time, a place, a purpose, and an identity; (3) markers are historically obdurate; (4) things act, and semiotics does not exhaust their significance. Arnold (2008) concluded that memory will be perceived in relation to the things that surround us - more particularly - in relations between things, and between ourselves and things (memories of relations, and sociotechnical systems).

The theoretical foundation described above was a background in the research of managers' perception of their activities. In the next section we present profiles of the observation and a survey that were research method used to verify hypotheses about managers perception and the real trajectory of management processes. 


\section{Observation and the survey profiles}

There were two measured processes in the research: setting goals and describing tasks. As the results of them there were two recondite things with certain features: a goal and a task (Flak, 2013, pp. 187-197). In projects that were being conducted by managers these two processes and their results shaped quite similar relationships to the relationships shown in the Figure 1. Processes (setting and describing) lead to results (goals and tasks). There is one difficult point in understanding this division. It is important to notice that tasks are also processes that should be taken by users (managers or their subordinates) in the future. However, describing the results we focused more on the processes than their results.

As we mentioned in the Introduction, the research on management processes was conducted by two ways of gathering data. The first way was the observation based on $\mathrm{TH}$ management tools that had been projected to play a role of an instrument for doing actions in managing a small project and to be a measurer of things and process. They are key elements described in the system of organizational terms (Flak, 2013, pp. 187-197). The tools were embedded in online platform and they recorded all action taken by users (managers of projects) during two main activities: setting goals and describing tasks.

The TH management tools consisted of a 'goaler' and a 'tasker'. Both tools were connected to each other and their functions depended on each other. The main goal of users was to prepare an implementation handbook for an innovative management tool. The processes were being monitored during 2 months.

The second way of gathering data was a survey for TH users. They were asked how they initiated processes and how they saw themselves as managers. The survey questionnaires were filled by managers of projects just after finishing their projects.

This approach let us solve some research dilemmas that every researcher encounters. There are two ontological assumptions: (1) external reality of processes; (2) process parts may be examined separately. An additional assumption was made in the field of epistemology. We assumed that the researcher might be separated from objects being researched (Seltsikas, 1999, p. 185).

Because in the observation we had only a small group of TH users (8 managers) we were not able to make an assumption that what is true at one time and in one place may also be true at another time and in another place. Additionally, we were conscious that our tools influenced somehow on the users' behaviours. Thus we did not make an axiological assumption that results of research are free of bias (Seltsikas, 1999, p. 185). 
As it was mentioned in the section above, our approach to processes based on Knowledge Management System. Except well-defined processes, an effective Knowledge Management System also needs an environment that encourages users to seek and acquire knowledge from internal and external sources. The process-based TH tools work as a driving mechanism to encourage a culture of knowledge management Keane, Barber and Munive-Hernandez, 2007, p. 135).

From the point of view of reusable knowledge, we constructed a business process pattern library by collecting reusable business processes as business process patterns. These business process patterns represent the flow of business activities, and they do not depend on the TH management tools and their implementation. As an example of a way of projecting the $\mathrm{TH}$ management tools and using them to collect data we used a model presented by Terai, Sawai, Sugiura, Izumi and Yamaguchi (2002). This model is presented in the Figure 2.

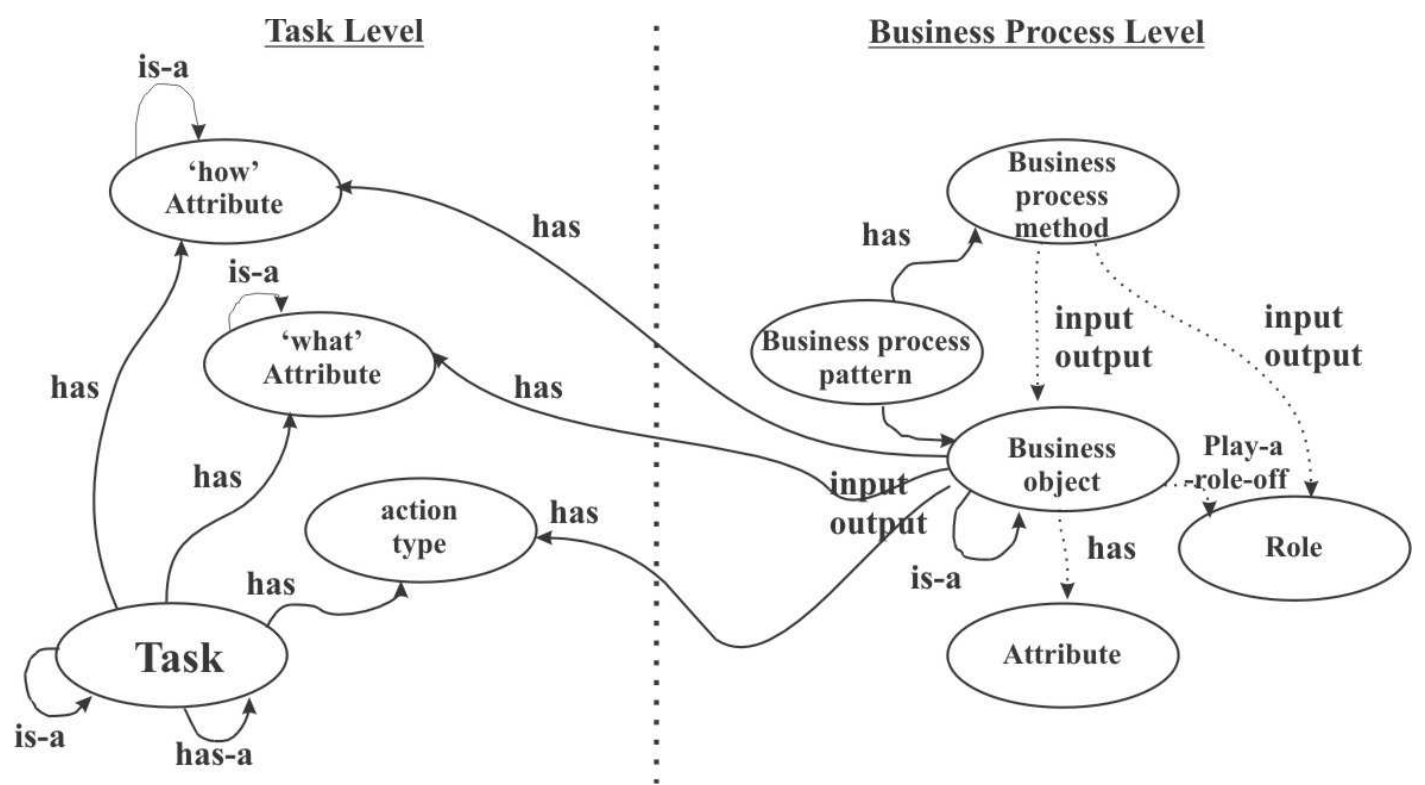

Figure 2. Meta model for business process level

Source: Terai, Sawai, Sugiura, Izumi and Yamaguch (2002), p. 223.

In order to describe why this model was a basis of our research it is worth mentioning several assumptions. They are presented in the Table 1. 
Table 1. Description of model elements

\begin{tabular}{|c|c|c|}
\hline & Object of the model & Description \\
\hline \multirow{4}{*}{ 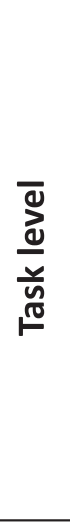 } & task & $\begin{array}{l}\text { Researched processes with TH management tools: } \\
\text { setting goals (the goaler tool) } \\
\text { describing tasks (the tasker tool) }\end{array}$ \\
\hline & "how" attribute & $\begin{array}{l}\text { A goal: measures for goals } \\
\text { A task: measures for tasks }\end{array}$ \\
\hline & "what" attribute & $\begin{array}{l}\text { A goal: a future state to obtain } \\
\text { A task: a verb what to do }\end{array}$ \\
\hline & action type & $\begin{array}{l}\text { add new \{goal; task\} } \\
\text { view }\{\text { goal; task\} } \\
\text { edit \{goal; task\} } \\
\text { delete \{goal; task\} }\end{array}$ \\
\hline \multirow{5}{*}{ 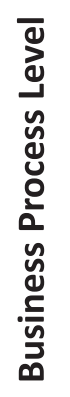 } & Business Process Pattern & Individual management pattern of any user \\
\hline & Business Process Method & The methods used by managers in the project \\
\hline & Business Object & The small project \\
\hline & Role & $\begin{array}{l}\text { Project managers played roles of users of the TH } \\
\text { management tools }\end{array}$ \\
\hline & Attribute & $\begin{array}{l}\text { The project concerned preparing an implementation } \\
\text { and instruction manual for an innovative } \\
\text { management tool }\end{array}$ \\
\hline
\end{tabular}

Readers can find two prototypes of the TH management tools in the platform http://www.transistorshead.com. There are two managerial tools - a goaler and a tasker - that have two main functions. The first of them is to let a manager conduct managerial processes (setting goals and describing tasks). The second function is to record data about processes. Previous experiments in little groups of managers, which were carried in 2012, proved that this method of research and such tools give a big number of data about managerial activities. When this paper was being written, the graph theory was being applied to make analysis of managerial tools in the area of setting goals and describing tasks.

So that the reader could check how the method of the research and the TH management tools work, it is possible to log in to transistorshead.com. The first account has been created so that a reader could see the results of an anonymous manager - John Smith. A login name: john.smith, a password: smith. The second account is open to changes and any reader can create examples of goals and tasks. It is also possible to modify goals and tasks created before. A login name: anonymous.manager, a password: manager. 


\section{Perception of management process and its real trajectory}

The questions in the questionnaire covered 9 fields of similarities or differences between the real trajectory of processes and managers' perception. They were as follow:

- The way of setting goals and describing tasks,

- The way of sharing tasks among team members,

- Frequency of goals changes,

- Number of goals changes,

- Number of tasks described for goals,

- Frequency of using tools by team members,

- Level of differences between goals which were set as first and their next versions,

- Influence level of goals' changes on changes of tasks' features,

- Influence level of tasks' changes on changes of goals' features,

In the Tables 2, 3, 4 there are comparisons of 3 most expended patterns of management processes. The "reality" rows contain the results of the observation. The "perception" rows include answers given by managers who were users of the TH management tools.

For the first manager, whose actions and answers are shown in the Table 2 , it is possible to point out several disparities between the real trajectory of processes and their perception. The manager claimed that the tasks were spread among members of his team (process: describing tasks). The real situation, recorded by the TH tools, was contrary. The manager answered that the goals were changed rarely (process: setting goals). However, we counted frequency and we reckoned the goals were often changed. What is really interesting, the manager remembered that the goal no. 1 was changed only once (process: setting goals). Actually, the goaler tool recorded two changes of the goal no. 1, both of them caused by the user. It means the user did not remember an important action such as changing a goal that was established before. Additionally, in real there were about $50 \%$ changes in goal measurements (process: setting goals). The user answered that he did only very little changes. He was also wrong about a scale of changes that was made in goals features by changing features of tasks (process: setting tasks). On the grounds of numeric data we assessed the changes as very little.

Other fields of the comparison were the same in the reality and the manager's perception. The comparison is shown in the Table 2. 
Table 2. Results of the research for a manager no. 1

\begin{tabular}{|c|c|c|c|c|c|}
\hline \multirow[b]{2}{*}{ Options } & \multicolumn{5}{|c|}{ The way of setting goals and describing tasks } \\
\hline & $\begin{array}{l}\text { We set up } \\
\text { goals as first } \\
\text { and then we } \\
\text { described } \\
\text { tasks. } \\
\text { x } \\
\text { x }\end{array}$ & $\begin{array}{l}\text { We described } \\
\text { tasks as first } \\
\text { and then we } \\
\text { set up goals. }\end{array}$ & $\begin{array}{l}\text { We acted } \\
\text { basing on the } \\
\text { organizational } \\
\text { cycle. }\end{array}$ & $\begin{array}{l}\text { Only one } \\
\text { person set } \\
\text { up goals and } \\
\text { described } \\
\text { tasks. }\end{array}$ & $\begin{array}{l}\text { We acted } \\
\text { basing on } \\
\text { a "trial and } \\
\text { error" rule. }\end{array}$ \\
\hline & \multicolumn{5}{|c|}{ The way of sharing tasks among team members } \\
\hline $\begin{array}{l}\text { Reality } \\
\text { Perception }\end{array}$ & $\begin{array}{l}\text { We did not } \\
\text { share. }\end{array}$ & $\begin{array}{l}\text { Nearly } \\
\text { everyone } \\
\text { had the same } \\
\text { tasks to do. }\end{array}$ & $\begin{array}{l}\text { Some of } \\
\text { members had } \\
\text { different tasks } \\
\text { to do. }\end{array}$ & $\begin{array}{l}\text { Nearly } \\
\text { everyone had } \\
\text { different tasks } \\
\text { to do. }\end{array}$ & $\begin{array}{l}\text { Everyone had } \\
\text { different tasks } \\
\text { to do. }\end{array}$ \\
\hline & \multicolumn{5}{|c|}{ Frequency of goals changes } \\
\hline $\begin{array}{l}\text { Options } \\
\text { Reality } \\
\text { Perception }\end{array}$ & Never & Rarely & Sometimes & $\begin{array}{l}\text { Often } \\
x\end{array}$ & Always \\
\hline & \multicolumn{5}{|c|}{ Number of goals changes } \\
\hline $\begin{array}{l}\text { Options } \\
\text { Reality } \\
\text { Perception }\end{array}$ & $\begin{array}{l}\text { Goal } 1 \\
2 \\
1 \\
\end{array}$ & $\begin{array}{l}\text { Goal } 2 \\
\text { Not exist } \\
\text { No answer }\end{array}$ & $\begin{array}{l}\text { Goal 3 } \\
\text { Not exist } \\
\text { No answer }\end{array}$ & $\begin{array}{l}\text { Goal } 4 \\
\text { Not exist } \\
\text { No answer }\end{array}$ & $\begin{array}{l}\text { Goal } \\
\text { Not } \\
\text { Noa }\end{array}$ \\
\hline & \multicolumn{5}{|c|}{ Number of tasks described for goals } \\
\hline $\begin{array}{l}\text { Options } \\
\text { Reality } \\
\text { Perception }\end{array}$ & $\begin{array}{l}\text { Goal } 1 \\
3 \\
3\end{array}$ & $\begin{array}{l}\text { Goal } 2 \\
\text { Not exist } \\
\text { No answer }\end{array}$ & $\begin{array}{l}\text { Goal } 3 \\
\text { Not exist } \\
\text { No answer }\end{array}$ & $\begin{array}{l}\text { Goal } 4 \\
\text { Not exist } \\
\text { No answer }\end{array}$ & $\begin{array}{l}\text { Goal } 5 \\
\text { Not exist } \\
\text { No answer }\end{array}$ \\
\hline $\begin{array}{l}\text { Options } \\
\text { Reality } \\
\text { Perception }\end{array}$ & Never & $\begin{array}{l}\text { Frequency of } \\
\text { We viewed or } \\
\text { changed the } \\
\text { content very } \\
\text { rarely. } \\
x \\
x\end{array}$ & $\begin{array}{l}\text { using tools by } t \\
\text { We viewed or } \\
\text { changed the } \\
\text { content from } \\
\text { time to time. }\end{array}$ & $\begin{array}{l}\text { We viewed or } \\
\text { changed the } \\
\text { content very } \\
\text { often. }\end{array}$ & $\begin{array}{l}\text { We used tools } \\
\text { all the time } \\
\text { when we were } \\
\text { working. }\end{array}$ \\
\hline & \multicolumn{5}{|c|}{$\begin{array}{c}\text { Level of differences between goals which were set as first and their next } \\
\text { versions }\end{array}$} \\
\hline $\begin{array}{l}\text { Options } \\
\text { Reality } \\
\text { Perception }\end{array}$ & $\begin{array}{l}\text { They were } \\
\text { unchanged. }\end{array}$ & $\begin{array}{l}\text { Very little } \\
\text { changes. }\end{array}$ & $\begin{array}{l}\text { More less } \\
\text { a half of goal } \\
\text { features. } \\
x\end{array}$ & $\begin{array}{l}\text { Very big } \\
\text { changes. }\end{array}$ & $\begin{array}{l}\text { They were } \\
\text { completely } \\
\text { changed. }\end{array}$ \\
\hline & \multicolumn{5}{|c|}{ Influence level of goals' changes on changes of tasks' features } \\
\hline $\begin{array}{l}\text { Options } \\
\text { Reality } \\
\text { Perception }\end{array}$ & $\begin{array}{l}\text { Very low } \\
\mathrm{x} \\
\mathrm{x}\end{array}$ & Low & Middle & High & Very high \\
\hline & \multicolumn{5}{|c|}{ Influence level of tasks' changes on changes of goals' features } \\
\hline $\begin{array}{l}\text { Options } \\
\text { Reality } \\
\text { Perception }\end{array}$ & $\begin{array}{l}\text { Very low } \\
x\end{array}$ & Low & Middle & High & Very high \\
\hline
\end{tabular}

Differences between perception and real activities of another manager are shown in the Table 3. The first difference occurred in the field of succession of setting goals and describing tasks. The manager did not remember an order 
of succession and he thought that only one person did it (the manager was default). We recorded a precise order: goals were set as first. Contrary to the first manager, the second manager thought he reset the first goal twice and the recorded data contained only one change (process: setting goals). Next difference was a perception of frequency of using tools by team members. Monitored team activity was quite poor and we had data to assess that the team changed the content of tools very rarely (processes: setting goals and describing tasks). The manager estimated higher frequency of using tools. He did not notice how many features of goals were reset after the first established action as well. He underestimated the number of features that had been changed (process: setting goals). There were also differences in influence of goals changes on tasks changes and the other way round (processes: setting goals and describing tasks). In both cases the manager evaluated the influence as higher than it was in reality.

In other areas of the comparison the manager had very precise view what he had done with TH tools. It is possible to say he was very conscious of his activities done in the project. Details of similarities between answers in a questionnaire and recorded data there is in the Table 2.

Table 3. Results of the research for a manager no. 2

\begin{tabular}{|c|c|c|c|c|c|}
\hline \multirow[b]{2}{*}{ Options } & \multicolumn{5}{|c|}{ The way of setting goals and describing tasks } \\
\hline & $\begin{array}{l}\text { We set up } \\
\text { goals as first } \\
\text { and then we } \\
\text { described } \\
\text { tasks. } \\
x\end{array}$ & $\begin{array}{l}\text { We described } \\
\text { tasks as first } \\
\text { and then we } \\
\text { set up goals. }\end{array}$ & $\begin{array}{l}\text { We acted } \\
\text { basing on the } \\
\text { organizational } \\
\text { cycle. }\end{array}$ & $\begin{array}{l}\text { Only one } \\
\text { person set } \\
\text { up goals and } \\
\text { described } \\
\text { tasks. }\end{array}$ & $\begin{array}{l}\text { We acted } \\
\text { basing on } \\
\text { a "trial and } \\
\text { error" rule. }\end{array}$ \\
\hline & \multicolumn{5}{|c|}{ The way of sharing tasks among team members } \\
\hline Options & $\begin{array}{l}\text { We did not } \\
\text { share. }\end{array}$ & $\begin{array}{l}\text { Nearly } \\
\text { everyone } \\
\text { had the same } \\
\text { tasks to do. }\end{array}$ & $\begin{array}{l}\text { Some of } \\
\text { members had } \\
\text { different tasks } \\
\text { to do. }\end{array}$ & $\begin{array}{l}\text { Nearly } \\
\text { everyone had } \\
\text { different tasks } \\
\text { to do. }\end{array}$ & $\begin{array}{l}\text { Everyone had } \\
\text { different tasks } \\
\text { to do. }\end{array}$ \\
\hline Reality & $x$ & & & & \\
\hline Perception & \multicolumn{5}{|c|}{ Frequency of goals changes } \\
\hline $\begin{array}{l}\text { Options } \\
\text { Reality } \\
\text { Perception }\end{array}$ & Never & $\begin{array}{l}\text { Rarely } \\
\mathrm{x} \\
\mathrm{x} \\
\end{array}$ & Sometimes & Often & Always \\
\hline & \multicolumn{5}{|c|}{ Number of goals changes } \\
\hline $\begin{array}{l}\text { Options } \\
\text { Reality } \\
\text { Perception }\end{array}$ & $\begin{array}{l}\text { Goal } 1 \\
1 \\
2\end{array}$ & $\begin{array}{l}\text { Goal } 2 \\
\text { Not exist } \\
\text { No answer }\end{array}$ & $\begin{array}{l}\text { Goal } 3 \\
\text { Not exist } \\
\text { No answer }\end{array}$ & $\begin{array}{l}\text { Goal } 4 \\
\text { Not exist } \\
\text { No answer }\end{array}$ & $\begin{array}{l}\text { Goal } 5 \\
\text { Not exist } \\
\text { No answer }\end{array}$ \\
\hline & \multicolumn{5}{|c|}{ Number of tasks described for goals } \\
\hline $\begin{array}{l}\text { Options } \\
\text { Reality }\end{array}$ & $\begin{array}{l}\text { Goal } 1 \\
1\end{array}$ & $\begin{array}{l}\text { Goal } 2 \\
\text { Not exist }\end{array}$ & $\begin{array}{l}\text { Goal } 3 \\
\text { Not exist }\end{array}$ & $\begin{array}{l}\text { Goal } 4 \\
\text { Not exist }\end{array}$ & $\begin{array}{l}\text { Goal } 5 \\
\text { Not exist }\end{array}$ \\
\hline Perception & 1 & No answer & No answer & No answer & No answer \\
\hline
\end{tabular}

Knowledge, Participation and Waste Management - Selected Problems, A. Ujwary-Gil (Ed.) 


\begin{tabular}{|c|c|c|c|c|c|}
\hline \multirow[b]{2}{*}{ Options } & \multicolumn{5}{|c|}{ Frequency of using tools by team members } \\
\hline & Never & $\begin{array}{l}\text { We viewed or } \\
\text { changed the } \\
\text { content very } \\
\text { rarely. } \\
x\end{array}$ & $\begin{array}{l}\text { We viewed or } \\
\text { changed the } \\
\text { content from } \\
\text { time to time. } \\
x\end{array}$ & $\begin{array}{l}\text { We viewed or } \\
\text { changed the } \\
\text { content very } \\
\text { often. }\end{array}$ & $\begin{array}{l}\text { We used tools } \\
\text { all the time } \\
\text { when we were } \\
\text { working. }\end{array}$ \\
\hline & \multicolumn{5}{|c|}{$\begin{array}{l}\text { Level of differences between goals which were set as first and their next } \\
\text { versions }\end{array}$} \\
\hline $\begin{array}{l}\text { Options } \\
\text { Reality } \\
\text { Perception }\end{array}$ & $\begin{array}{l}\text { They were } \\
\text { unchanged. }\end{array}$ & $\begin{array}{l}\text { Very little } \\
\text { changes. }\end{array}$ & $\begin{array}{l}\text { More less } \\
\text { a half of goal } \\
\text { features. }\end{array}$ & $\begin{array}{l}\text { Very big } \\
\text { changes. } \\
x\end{array}$ & $\begin{array}{l}\text { They were } \\
\text { completely } \\
\text { changed. }\end{array}$ \\
\hline & \multicolumn{5}{|c|}{ Influence level of goals' changes on changes of tasks' features } \\
\hline $\begin{array}{l}\text { Options } \\
\text { Reality } \\
\text { Perception }\end{array}$ & $\begin{array}{l}\text { Very low } \\
x\end{array}$ & Low & Middle & High & Very high \\
\hline & \multicolumn{5}{|c|}{ Influence level of tasks' changes on changes of goals' features } \\
\hline $\begin{array}{l}\text { Options } \\
\text { Reality } \\
\text { Perception }\end{array}$ & $\begin{array}{l}\text { Very low } \\
x\end{array}$ & Low & Middle & High & Very high \\
\hline
\end{tabular}

The perception and the real trajectory of the third manager differs to a large extent. For example, we recorded a very chaotic way of managing. Nevertheless, the manager did not realize that he and his team acted this way (processes: setting goals and describing tasks). Another difference concerned the way of sharing tasks among team members. The manager thought some of members had different tasks to do. On the grounds of recorded data we assessed that nearly everyone in his team had different tasks to do (process: describing tasks). Next difference occurs in the field of frequency of goals changes. Comparing to real facts the manager overestimated the number of the changes in goals' features (process: setting goals).

What is really amazing in this case, the manager had completely different knowledge about a number of goals he had set (process: setting goals). He pointed in the survey that he had set 5 different goals during the project. In fact there were only two goals. He did not remember the number of goals changes as well. For the goal no. 1 he was conscious of 2 changes. However, the tool did not record any change. Moreover, he manager did not remember how many tasks were established in the project (process: describing tasks).

The next field of the comparison also gives great discrepancy. We assessed that the manager viewed or changed the content very often. He noticed it was very rarely. He also overestimated the influence level of tasks' changes on changes of goals' features (processes: describing tasks), although he underestimated the influence level of goals' changes on changes of tasks' features (setting tasks). 
Table 4. Results of the research for a manager no. 3

\begin{tabular}{|c|c|c|c|c|c|}
\hline \multirow[b]{2}{*}{ Options } & \multicolumn{5}{|c|}{ The way of setting goals and describing tasks } \\
\hline & $\begin{array}{l}\text { We set up } \\
\text { goals as first } \\
\text { and then we } \\
\text { described } \\
\text { tasks. } \\
x \\
x\end{array}$ & $\begin{array}{l}\text { We described } \\
\text { tasks as first } \\
\text { and then we } \\
\text { set up goals. }\end{array}$ & $\begin{array}{l}\text { We acted } \\
\text { basing on the } \\
\text { organizational } \\
\text { cycle. }\end{array}$ & $\begin{array}{l}\text { Only one } \\
\text { person set } \\
\text { up goals and } \\
\text { described } \\
\text { tasks. }\end{array}$ & $\begin{array}{l}\text { We acted } \\
\text { basing on } \\
\text { a "trial and } \\
\text { error" rule. } \\
x\end{array}$ \\
\hline & \multicolumn{5}{|c|}{ The way of sharing tasks among team members } \\
\hline $\begin{array}{l}\text { Reality } \\
\text { Perception }\end{array}$ & $\begin{array}{l}\text { We did not } \\
\text { share. }\end{array}$ & $\begin{array}{l}\text { Nearly } \\
\text { everyone } \\
\text { had the same } \\
\text { tasks to do. }\end{array}$ & $\begin{array}{l}\text { Some of } \\
\text { members had } \\
\text { different tasks } \\
\text { to do. }\end{array}$ & $\begin{array}{l}\text { Nearly } \\
\text { everyone had } \\
\text { different tasks } \\
\text { to do. } \\
x\end{array}$ & $\begin{array}{l}\text { Everyone had } \\
\text { different tasks } \\
\text { to do. }\end{array}$ \\
\hline Perception & \multicolumn{5}{|c|}{ Frequency of goals changes } \\
\hline $\begin{array}{l}\text { Options } \\
\text { Reality } \\
\text { Perception }\end{array}$ & Never & $\begin{array}{l}\text { Rarely } \\
\mathrm{x}\end{array}$ & Sometimes & Often & Always \\
\hline Perception & \multicolumn{5}{|c|}{ Number of goals changes } \\
\hline $\begin{array}{l}\text { Options } \\
\text { Reality } \\
\text { Perception }\end{array}$ & $\begin{array}{l}\text { Goal } 1 \\
0 \\
2 \\
\end{array}$ & $\begin{array}{l}\text { Goal } 2 \\
1 \\
1 \\
\end{array}$ & $\begin{array}{l}\text { Goal } 3 \\
\text { Not exist } \\
2\end{array}$ & $\begin{array}{l}\text { Goal } 4 \\
\text { Not exist } \\
2\end{array}$ & $\begin{array}{l}\text { Goal } 5 \\
\text { Not exist } \\
1\end{array}$ \\
\hline Perception & \multicolumn{5}{|c|}{ Number of tasks described for goals } \\
\hline $\begin{array}{l}\text { Options } \\
\text { Reality } \\
\text { Perception }\end{array}$ & $\begin{array}{l}\text { Goal } 1 \\
8 \\
\text { No answer }\end{array}$ & $\begin{array}{l}\text { Goal } 2 \\
\text { Deleted } \\
\text { No answer }\end{array}$ & $\begin{array}{l}\text { Goal } 3 \\
\text { Not exist } \\
\text { No answer }\end{array}$ & $\begin{array}{l}\text { Goal } 4 \\
\text { Not exist } \\
\text { No answer }\end{array}$ & $\begin{array}{l}\text { Goal } 5 \\
\text { Not exist } \\
\text { No answer }\end{array}$ \\
\hline \multicolumn{6}{|c|}{ Frequency of using tools by team members } \\
\hline $\begin{array}{l}\text { Reality } \\
\text { Perception }\end{array}$ & Never & $\begin{array}{l}\text { We viewed or } \\
\text { changed the } \\
\text { content very } \\
\text { rarely. }\end{array}$ & $\begin{array}{l}\text { We viewed or } \\
\text { changed the } \\
\text { content from } \\
\text { time to time. }\end{array}$ & $\begin{array}{l}\text { We viewed or } \\
\text { changed the } \\
\text { content very } \\
\text { often. } \\
x\end{array}$ & $\begin{array}{l}\text { We used tools } \\
\text { all the time } \\
\text { when we were } \\
\text { working. }\end{array}$ \\
\hline & \multicolumn{5}{|c|}{$\begin{array}{l}\text { Level of differences between goals which were set as first and their next } \\
\text { versions }\end{array}$} \\
\hline $\begin{array}{l}\text { Options } \\
\text { Reality } \\
\text { Perception }\end{array}$ & $\begin{array}{l}\text { They were } \\
\text { unchanged. }\end{array}$ & $\begin{array}{l}\text { Very little } \\
\text { changes. } \\
x\end{array}$ & $\begin{array}{l}\text { More less } \\
\text { a half of goal } \\
\text { features. }\end{array}$ & $\begin{array}{l}\text { Very big } \\
\text { changes. }\end{array}$ & $\begin{array}{l}\text { They were } \\
\text { completely } \\
\text { changed. }\end{array}$ \\
\hline & \multicolumn{5}{|c|}{ Influence level of goals' changes on changes of tasks' features } \\
\hline $\begin{array}{l}\text { Options } \\
\text { Reality } \\
\text { Perception }\end{array}$ & Very low & Low & Middle & High & $\begin{array}{l}\text { Very high } \\
\mathrm{x}\end{array}$ \\
\hline & \multicolumn{5}{|c|}{ Influence level of tasks' changes on changes of goals' features } \\
\hline $\begin{array}{l}\text { Options } \\
\text { Reality } \\
\text { Perceptio }\end{array}$ & $\begin{array}{l}\text { Very low } \\
x\end{array}$ & Low & Middle & High & Very high \\
\hline
\end{tabular}




\section{Conclusion}

An important element of decision-making, especially for managers is their perception of their own activities. We had a chance to do the research during which we compared real trajectories of actions (management processes) and managers' perception of them. Contributing to both the theoretical background in process management and theories of human perception in literatures, we found the effects really astonishing.

Firstly, we proved the hypothesis $\mathrm{H} 1$ to be true. Managers are not conscious of most of their activities in management process. Following the reasoning set forth by results of the observation and the survey, we claim that managers as humans have big problems acting reasonably. We agreed with Latour and his theory of memory that we presented above (Latour 1999). According to the content of Tables 2, 3, 4 managers did not have memory located solely "in the mind", but their perception of actions they did resides in things, in relations between things, and relations between things and humans. In this case the most important things were the TH management tools. It is a contrary reasoning to common positivist approach in management science. This approach let us believe that a manager is mostly rational and conscious of his activities.

Secondly, we also agreed with the hypothesis H2. Seemingly, it is obvious. However when we realize what consequences such a statement may cause in the organization, we could come to a conclusion that the higher level manager in the organization the higher level of his unconsciousness. Further research is needed to study these issues. We hope it will help to verify Austin \& Vancouver four-steps of action described above.

As an example of similar conclusions there are results that were conducted by Researchers in the European Commission's Artificial Development Approach to Presence Technologies (ADAPT). In their project they used a model of the human sense of presence on the grounds of a combination of senses like sight, hearing and touch. They used the torso of a 2-year-old child to understand human perception to develop machines that can perceive and interact with their environments. To analyse the perception process they developed a model of consciousness using artificial objects as a part of a process of perception. The results were amazing. As most theories describe consciousness as: (a) perception, (b) cognition, (c) action, they achieved a reverse order: (a) action, (b) cognition, (c) perception (Computerworld, 2006, p. 36). Our findings are therefore close to such a conclusion about way of managing by managers who took part in our research.

Finally, it would be interesting to study differences in a bigger numbers of managers then in our research. Such research could also provide conclusions about the influence of tools on managers' actions and let attempt to automatize 
management processes in order to replace a manager by a machine in the future.

\section{References}

Armitage, C. J. (2004). Evidence that implementation intentions reduce dietary fat intake: A randomized trial. Health Psychology, 23(3), 319-323.

Arnold, M., Shepherd, Ch., Gibbs, M. (2008). Remembering things. The Information Society, 24, 47-53.

Babybot Helps Researchers explore human perception (2006). Computerworld, $5 / 22,40(21), 36-36$.

Bem, D.J. (1972). Self-perception theory. In: L. Berkowitz (Ed.), Advances in Experimental Social Psychology, 6, 1-62. New York: Academic Press.

Bolino, M.C., Jaron, H., Bachrach, D.G. (2012). A self-regulation approach to understanding citizenship behavior in organizations. Organizational Behavior and Human Decision Processes, 119, 126-139.

DeCharms, R. (1983). Personal Causation: The Internal Affective Determinants of Behavior. Hillsdale, NJ: Lawrence Eribaum.

Dholakia, U.M., Bagozzi, R.P., Gopinath, M. (2007). How formulating implementation plans and remembering past actions facilitate the enactment of effortful decisions. Journal of Behavioral Decision Making, 20, 343-364.

Dowdle, P., Stevens, J., McCarty, B., Daly, D. (2005). The process-based management loop. The Journal of Corporate Accounting \& Finance, January/February, 55-61.

El-Diraby, T. A., Lima, C., Feis, B. (2005). Domain taxonomy for construction concepts - toward a formal ontology for construction knowledge, Journal of Computing in Civil Engineering, ASCE, October, 394-406.

Flak, O. (2008). Konceptualizacja układu wielkości organizacyjnych. In: A. Nalepka (Ed.), Organizacje komercyjne i niekomercyjne wobec wzmożonej konkurencji oraz wzrastajqcych wymagań konsumentów. Nowy Sącz: Wyższa Szkoła Biznesu - National-Louis University.

Flak, O. (2013). Concept of Managerial Tools Based on the System of Organizational Terms. In: R. Knosala (Ed.), Innovations in Management and Production Engineering. Opole: Oficyna Wydawnicza Polskiego Towarzystwa Zarządzania Produkcją.

Gollwitzer, P. M. (1990). Action phases and mind-sets. In: E. T. Higgins, R. M. Sorrentino (Eds.). The Handbook of Motivation and Cognition: Foundations of Social Behavior, 2, 53-92. New York: Guilford Press.

Gollwitzer, P. M. (1999). Strong effects of simple plans. American Psychologist, 54(7), 493-503.

Grajewski, P. (2007). Organizacja procesowa. Warszawa: PWE.

Janiszewski, Ch., Tavasolli, N.T. (2013). The influence of selective attention and inattention to products on subsequent choice. Journal of Consumer Research, 39, April, 1258-1274. 
Keane, J.P., Barber, K.D., Munive-Hernandez, J.E, (2007). Towards a learning organisation: The application of process-based knowledge maps to asset management (a case study). Knowledge and Process Management, 14(2), 131-143.

Laird, J.D., Bresler, C. (1992). The process of emotional feeling: A selfperception theory. In: M. Clark (Ed.) Emotion: Review of Personality and Social Psychology, 13, 223-234. Newbury Park, CA: Sage.

Lord, R. G., Diefendorff, J. M., Schmidt, A. M., Hall, R. J. (2010). Self-regulation at work. Annual Review of Psychology, 61, 543-568.

Keightley, E. (2010). Remembering research: memory and methodology in the social sciences. International Journal of Social Research Methodology, 13(1), February, 55-70.

Nisbett, R.B., Wilson, T.D. (1977). Telling more than we can know: Verbal reports on mental processes. Psychological Review, 84, 231-259.

Pettigrew, A.M. (1997). What is a processual analysis? Scandinavian Journal of Management, 13(4), 337-348.

Robak, R.W., Ward, A. (2006). Development of a general measure of individuals' recognition of their self-perception processes. North American Journal of Psychology, 8(1), 337-344.

Rohloff, M. (2011). Advances in business process management implementation based on a maturity assessment and best practice exchange. Inf Syst E-Bus Manage, 9, 383-403.

Seltsikas, P. (1999). Information management in process-based organizations: a case study at Xerox Ltd. Info Systems, 9, 181-195.

Skrzypek, E., Hofman, M. (2010). Zarzq̨dzanie procesami w przedsiębiorstwie. Warszawa: Wolters Kluwer Polska.

Terai, K., Sawai, M., Sugiura, N., Izumi, N., Yamaguchi, T. (2002). Business process semi automation based on business model management, International Journal of Intelligent Systems in Accounting, Finance \& Management, Published online in Wiley InterScience (www.interscience.wiley.com). DOI: 10.1002/isaf.237.

Vancouver, J. B., Day, D. V. (2005). Industrial and organisation research on selfregulation: From constructs to applications. Applied Psychology: An International Review, 54, 155-185.

Zieleniewski, J. (1961). Organizacja zespołów ludzkich. Warszawa: PWN.

Shackle, G.K.S. (1961). Decision Order and Time in Human Affairs. Cambridge: Cambridge University Press. 


\begin{abstract}
Abstrakt (in Polish)
Celem artykułu jest zaprezentowanie wyników badań dotyczq̨cych zachowań menedżerów. Autorzy podjęli próbę odkrycia głównych różnić pomiędzy trajektoriq procesów podejmowanych przez menedżerów i ich percepcja tych procesów po zakończeniu projektu. W pierwszej części artykułu zamieszczono podstawy teoretyczne zarzqdzania procesami, a wnioski wyciagnięte na podstawie literatury przedmiotu doprowadziły do zbudowania modelu badania. W drugiej części artykułu autorzy przedstawiajq obecny stan wiedzy na temat percepcji człowieka i samoświadomości podejmowanych przez niego działań. Następnie opisano założenia przeprowadzonego badania oraz metody badawcze. W badaniu wykorzystano metodę obserwacji i metodę ankiety. Obserwacji dokonano za pomoca informatycznych narzędzi online, które w czasie badania rejestrowały aktywność menedżera w zakresie podejmowanych przez niego procesów zarzqdzania. W ostatniej części artykułu zaprezentowano również trzy przykłady różnić pomiędzy faktycznq trajektoriq procesów zarzq̨dzania oraz ich percepcjq przez menedżerów. We wstępie artykułu sformułowano dwie hipotezy badawcze, które zweryfikowano w ostatniej części artykułu na podstawie zaprezentowanych wyników badań.
\end{abstract}

Słowa kluczowe: zarzqdzanie procesami, percepcja człowieka, trajektorie procesów, układ wielkości organizacyjnych. 